\title{
'Pretenders of a Vile and Unmanly Disposition': Thomas Hobbes on the Fiction of Constituent Power
}

\author{
Adam Lindsay \\ School of Politics and International Relations, University of Nottingham \\ adam.lindsay3@nottingham.ac.uk
}

The prevailing interpretation of constituent power is taken to be the extra-institutional capacity of a group, typically 'the people', to establish or revise the basic constitutional conditions of a state. Among many contemporary democratic theorists, this is understood as a collective capacity for innovation. This paper excavates an alternative perspective from constituent power's genealogy. I argue that constituent power is not a creative material power, but is a type of political claim that shapes the collective rights, responsibilities and identity of 'the people'. I do so by recovering Thomas Hobbes's intervention into debates over constituent power among Scottish Presbyterians during the English Civil War. Though a materialist, Hobbes appreciated the centrality of the imagination to politics, and he argued that constituent power was one such phantasm of the mind. In Leviathan, he showed constituent power not to be a material power, but a world-making fiction that furnished political realities with ornamentation of the imagination, which might provide the beliefs and justifications to serve any number of political ends. More generally, the retrieval of a Hobbesian constituent power provides an important challenge to contemporary theories by demonstrating how partisan constructions of constituent power shape the political options available to groups.

\section{KEY WORDS}

Thomas Hobbes, Constituent Power, imagination, the People, representation, democratic theory

\section{ACKNOWLEDGEMENT}

For comments on earlier versions of this paper, I am grateful to Michael Freeden, Duncan Kelly, Helen McCabe, Chris Pierson and Mark Wenman. For his persistence with several such drafts, special thanks go to Ben Holland. I would also like to thank Lawrie Balfour and the anonymous reviewers for their productive feedback. 


\section{'Pretenders of a Vile and Unmanly Disposition': Thomas Hobbes on the Fiction of Constituent Power}

In chapter 18 of Leviathan, Thomas Hobbes described a group of seditious Presbyterians as 'pretenders... of a vile and unmanly disposition'. 'The source of Hobbes's outrage was the contract that they purported to have constructed in service to their disobedience to the King. These arguments were a variation on early modern theories of constituent power, which Hobbes sought to reveal as a dangerous and underhand fiction that exploited the imagination of fellow believers. The recovery of Hobbes's neglected condemnation of these Presbyterians, the Scottish Covenanters, has much to offer contemporary theories of constituent power. Constituent power commonly refers to the extra-institutional capacity of a group to establish or revise the basic constitutional conditions of a state. Among many contemporary democratic theorists, this is understood as a materialist potentia or a voluntarist capacity to enact change. Andreas Kalyvas, following Carl Schmitt, associates constituent power with the establishment of government through 'human will', analogous to 'physical natality'. ${ }^{2}$ Mark Wenman arrives at the same conclusion by following Antonio Negri. He defines it as a 'capacity for innovation', which he sharply distinguishes from 'power qua right (potestas) ${ }^{3}$. As a dynamic capacity for innovation that might manifest either in the potential of a decentralised multitude, or a mode of insurgent citizenship, constituent power has become a pivotal instrument within the toolkit of political and legal theorists engaged in constitutionalism. ${ }^{4}$ Though these reflections have provided valuable reconsiderations of what might count as valid democratic activity, they also fix constituent power within relatively unchanging parameters, namely, as the vehicle for political contestation borne by the ostensible 'creators' of the state.

The purpose of this article is to retrieve another way of thinking about constituent power. I argue that it is not a capacity for self-legitimising collective innovation, but serves as one tool among the many fictional components of our political language that contribute to the rich, layered thought- 
practices that comprise and pattern political thinking. 'Constituent power' is a malleable element of our political vocabulary that, when incorporated into arguments, supplements and shapes partisan claims over the meaning and content of collective representative tropes, such as 'the people'.

This, I argue, is how Thomas Hobbes interpreted constituent power. In Leviathan, Hobbes intervened into debates over political supremacy among Presbyterian theologians, and, in doing so, disclosed an alternative conceptualisation of constituent power. Hobbes understood it not as a material power, but what he called a 'fancy'. This was a flight of the imagination that ornamented motion with supplementary normative commitments that, when formulated as it was by the Presbyterians, could excite men into seditious acts. Though he intended to reveal the Presbyterian constituent power as a fiction, his aim was not deflationary. Hobbes harnessed the same tools for his own political project because he recognised the centrality of the imagination to maintaining the fictional attribution of political responsibility that allowed the state to exist.

This article proceeds as follows: I first account for some contemporary interpretations of constituent power, with particular attention to how Hobbes's work is used to distinguish it from sovereignty. Doing so will allow me in the later sections to sharpen part of the conceptual history of constituent power, which has been habitually understood to have emerged as a democratic counterpoint to Hobbesian absolutism. One aim of this paper is to show that it has a more complex conceptual history, of which Hobbes is a central part. There is also much to be gained from interpreting Hobbes's particular conception of constituent power. In addition to deepening our understanding of the political context within which Hobbes wrote Leviathan, Hobbes provided the additional theoretical apparatus to recognise constituent power as a particular type of claim capable of aiding a broad range of political purposes. To demonstrate this, I turn in the second and third sections to Hobbes's account of imagination. Though this has much to say about Hobbes's opposition to the scholasticism taught in the University, ${ }^{5}$ it is also pertinent to debates over the constituent power of the people that resurfaced among Scottish Presbyterians during the English Civil War. In the second section, I unpack Hobbes's mechanistic theory of the imagination. In the 
third, I show how this was used by Hobbes to defuse the Covenanter arguments that undermined the supremacy of the king, before using constituent power to supplement his account of representation for the purpose of obedience.

This point is deepened in the final part of the article, where this argument is extended into contemporary debates. The core argument that I advance is that although constituent power is world-making, it does not denote a capacity for innovation-as is does for many contemporary democratic theorists. It is a world-making fiction. This deepens one aspect of the way in which peoplehood is understood. If images of peoplehood are constructed through claim-making, constituent power serves as one metaphor that shapes the various normative commitments of a group, substantiating who possesses political authority, the sorts of political actions that are legitimised by that authority, and the ends to which those actions should be directed.

\section{On the Conceptual History of CONSTITUEnT Power}

Thomas Hobbes is rarely read as a theorist of constituent power. Although Hobbes's social contract appears to make foundational to the commonwealth by institution a body politic that is democratic in origin, there is some agreement that constituent power eludes the Hobbesian version of contractualism. ${ }^{6}$ Those that do recognise the place of Hobbes within its conceptual history interpret his absolutism as the foil against which an inchoate constituent power emerged in EarlyModern Europe. ${ }^{7}$ As I will go on to argue in subsequent sections, this intuition is flawed because Hobbes is the antihero, not the villain, of this story. First, in this section, I show how modern scholars use Hobbes's writing as a counterpoint in the conceptual history of constituent power in order to control its meaning as a brand of extra-constitutional collective agency. Though there are some quite significant disagreements among theorists of constituent power, ${ }^{8}$ these differences operate within relatively fixed parameters. In this section, I bring to light some ways in which these component assumptions are reproduced when positioning the genesis of constituent power as a response to Hobbes. 
Andreas Kalyvas writes, 'constituent power is the truth of modern democracy'. It is so because 'the birth of the modern doctrine of popular sovereignty coincides with the conceptual advent of constituent power. ${ }^{9}$ Here, Kalyvas advances two distinctive forms of origin claim. Constituent power is the truth of modern democracy because it resides at the origin of the modern political community —insofar as it is the power that establishes any particular democratic community. It is also the truth of modern democracy because, for Kalyvas, democracy is found at the conceptual origin of constituent power. ${ }^{10}$ What is notable about Kalyvas's depiction is the implication that its historically 'first' articulation should have conceptual priority over its meaning. Here, he engages a rhetorical strategy that exploits the Aristotelian presumption that at an origin one finds the essence of an entity. ${ }^{11}$ This exploitation cements the relationship between a word-'constituent power'and cluster of concepts—namely, an authentic, extra-constitutional collective capacity-by employing a privileged origin as a means of 'decontesting' the meaning of that word by ruling out alternatives and capturing it for a particular political programme. ${ }^{12}$

In service to this argument, Kalyvas locates his origin of an inchoate constituent power in George Lawson's Politica Sacra et Civilis, as a direct contrast—both conceptually and historically — to Hobbes' Leviathan. ${ }^{13}$ Lawson's distinction between majestas realis and majestas personalis proposed that 'real' sovereignty, possessed by the community, was superior to the personal sovereignty of the constituted monarch. ${ }^{14}$ When framed as a response to Hobbes, Kalyvas portrays constituent power as a counter-tradition of modernity that represents an 'alternative definition' of political power exemplified by a capacity for creation and differs significantly from the paradigm of sovereignty-ascommand. ${ }^{15}$ To maintain this assertion, Kalyvas puts Lawson's and Hobbes's arguments to work in order to structure a conceptual bifurcation of political power: the transcendent command that underwrites the extant political regime, against the immanent creativity that ruptures it. ${ }^{16}$ Central to the decontestation of this conceptual bracketing is Kalyvas's assertion that constituent power emerged in the wake of Hobbesian absolutism, and established a counter-tradition of modern 
political power that tied Lawson to Locke, Paine, Sieyès, and even Schmitt, running parallel to sovereignty-as-command through the history of modern Western thought. ${ }^{17}$

The plausibility of this interpretation is possible, in part, because Hobbes is marginalised within the genealogy, serving only as the absolutist foil against which arguments about constituent power were positioned. In doing so, Kalyvas and others sharpen the conceptual opposition between constituent power and sovereignty-as-command in order to celebrate the former and denounce the latter. Not only is this artificial distinction less tenable in light of recent scholarship that has shown the early modern theories of Bodin and Hobbes to be less absolutist than once presumed, ${ }^{18}$ it also occludes the varied ends to which constituent power has been used in the history of political thought.

The intention of this article, then, is to challenge the conceptual backbone that contrasts constituent power with sovereign power by excavating a critical moment in its history. This moment is Thomas Hobbes's engagement in Leviathan with the Scottish Presbyterians. Only Murray Forsyth has made the sustained attempt to portray Hobbes as a theorist of constituent power, though his argument operates through analogy by tracing the conceptual continuities between Hobbes and Emmanuel Sieyès. ${ }^{19}$ Mónica Brito Vieira, then, is quite right to challenge Forsyth's imputation of Sieyès back into Hobbes ${ }^{20}$ However, her conclusion that it is 'misleading' to describe Hobbes as a theorist of constituent power because his theory did not comprise the pre-legal collective subject that Sieyès's did only repeats the assumption that constituent power is a collective will antithetical to representative politics. She excludes the possibility that Hobbes may have developed his own account that need not resemble Sieyès's much later formulation. By Leviathan, Hobbes wished to debunk the view that a power was possessed immediately by a group such as the people. However, he wished to do so without abandoning the concept of constituent power. He did this by demonstrating that constituent power was nothing more than a label that designates a flight of the imagination that embellished political acts with the requisite normative commitments for either rebellion or obedience. 


\section{HOBBES, IMAGINATION, AND SEDITION}

Imagination as a manifestation of sense perception was a topic to which Hobbes often returned, and out of more than mere scientific curiosity. ${ }^{21}$ In $D e$ Corpore, he provided a thought experiment in which we are to assume the annihilation of the world bar a single man. Supposing enough sensory data had made an impression upon his mind prior to this hypothetical annihilation, Hobbes argued that this man would still have access to a simulated world which, 'though they be nothing but ideas and phantasms...they will appear as if they were external, and not at all depending upon any power of the mind. ${ }^{22}$ Imagination was, for Hobbes, a formidable fulcrum around which a political world pivoted. This was made clear in the closing pages of Leviathan, in which he analogised the Papacy to a 'Kingdome of Fairies'. Just as fairies had 'no existence, except in the Fancies of ignorant people', so too, the power of the papacy was maintained only by fear-inducing imagery of dæmonology. ${ }^{23}$ Hobbes's point was that the imagination was an aspect of mental cognition that could be strategically exploited to supplement basic physical powers for the purpose of securing obedience. Accordingly, in this section I show how Hobbes developed this argument to dispel the fantastic illusions that supported the power of the church. This is crucial to the position that I present in third part of the article, namely, that it was this deflationary approach to sæcerdotal power that Hobbes imported when responding to arguments about constituent power in Scottish Covenanter theology.

Hobbes's theory of the imagination was constructed as part of a sustained confrontation with the Aristotelian theories of sense perception that dominated late scholastic textbooks. ${ }^{24}$ Aristotelian sense perception hung on the potentiality-actuality distinction, whereby the object being perceived was thought to alter the sensory organ and actualise a potentiality within it. ${ }^{25}$ For example, the emission of the colour red from the sensible object also made the relevant sensory organ, the eye, red. This entailed the acquisition of the qualities of the perceptible essence without also acquiring the matter. ${ }^{26}$ Scholastic interpreters of Aristotle understood this to take the form of a 'separated 
essence', which bore the qualities of the object from which they were emitted, activating the sensory faculties in the recipient. ${ }^{27}$

Hobbes rejected the intuition behind scholastic sense perception. Hobbes was, after all, a materialist and a nominalist who believed nothing existed beyond the magnitude and motion of bodies. ${ }^{28}$ The doctrine of separated essences breached this materialism by presuming that something incorporeal could exist independently of matter. Influenced by the early modern scientific revolution, Hobbes devised his own account of sense perception that was not reliant upon emission of essences. This was explained according to the principles of mechanistic physics laid out in De Corpore, which subscribed to the basic principle that 'all alteration is motion'. ${ }^{29}$ Sight, for instance, rather than qualitatively altering the eye, was simply explained as a local pressure exerted on the optical nerve. The sense organ did not receive the essence of the sensible object-colour, for Hobbes, was not inherent in the object—but was pressed by a motion or pulse of the sensible object that had been carried through a 'diaphanous [though corporeal] medium', such as air or water, causing the impression of colour in the observer..$^{30}$

With this mechanistic physics in place, Hobbes explained 'imagination' not as a distinct faculty of the mind that mediated between sense and intellect, as it was for the Scholastics, but only as the 'decaying sense' that followed motion pressing upon the sensory organ. ${ }^{31}$ When pressure upon the sense organ is interrupted, motion within the sense organ may continue just as ripples continue across water even once a stone thrown into a pond has sunk to the bottom and ceased to move. The waning impression of something formerly perceived by the sense organ is the imagination, and this may be received in various ways. It may be 'simple', where the sensory data was received at once, as in the case of a horse, or it may be 'compound', where a new mental object is composed from various perceived objects, such as the image of a Centaur. A product of the compound imagination is 'properly but a Fiction of the mind'. 32

Armed with a mechanistic account of the imagination, in chapter 46 of Leviathan Hobbes dismantled the 'vain philosophy of Aristotle' that inhabited the universities and the church. Hobbes 
argument had an elegant simplicity. Motion was the first principle of physics, and motion was to be understood as change of place. Because incorporeal essences were not capable of place, they could not be capable of motion, and therefore could not exist. To suggest otherwise was to hypostatise words, which were nothing more than nominal labels that had left 'an Impression in the Imagination'. Hobbes's point was that abstract nouns were not an indication of a separated essence, but were only 'signes, by which... wee conceive the Consequence of one name or Attribute to another'. ${ }^{33}$ The effect of this Scholastic 'error' was to presume the objective reality of incorporeal 'fancies', such as ghosts, fairies and the 'fabulous Doctrine concerning Dæmons', all of which were 'but Idols, or Phantasms of the brain, without any real nature of their own, distinct from human fancy'. ${ }^{34}$ This did not diminish their importance. These compound images, or 'fancies' produced an affective 'vibration' within the observer's body 'in sympathy with the fancy,' producing an emotive response that could strike fear or foster excitement in an individual. ${ }^{35}$ In its most insidious form, scholastic philosophy simply furnished a religious worldview in which it was possible to presume the persistence of the soul after death, and, with it, instil fear into citizens to obey the church over the state.

These details are important because they demonstrate that Hobbes's account of sense perception was not a technical exercise but was developed as part of a precise political engagement with the partisans of the civil war, and his materialist account of the imagination was a weapon he honed to fight that battle. Hobbes's intention was not only to unmask the intellectual emptiness of the Church, but also to demonstrate the Church to be wilfully complicit in peddling seditious fictions. ${ }^{36}$ Hobbes believed that scholastic philosophy furnished various sets of insincere arguments that allowed the Church to secure obedience through fear-inducing mythology, and this, at the very bottom, had caused the civil war. ${ }^{37}$ More pointedly, it was Hobbes's mechanistic understanding of the imagination that laid the groundwork upon which he was able to uncloak these church doctrines of dæmonology, the immortality of the soul, and, as I will show, constituent power, and to reveal 
them as nothing more than myth-making exercises on the part of the Catholic and Presbyterian clergy.

\section{On the Seditious Fiction of Constituent Power}

Though much has been written of Hobbes's general critique of the scholastic ontology that undergirded the Catholic and Presbyterian churches, ${ }^{38}$ far less has been said about Hobbes's treatment of particular instances of seditious speech and their effects. In Chapter 18 of Leviathan, 'Of the Rights of Soveraignes by Institution', Hobbes drew attention to one such case, the writers of which he caustically labelled 'vile and unmanly' pretenders. These men were early theorists of constituent power who, much like the clergy who made use of the doctrine of separated essences, conjured a fanciful fiction for seditious ends. It was the fiction of a divine covenant:

And whereas some men have pretended for their disobedience to their Soveraign, a new Covenant, made, not with men, but with God; this also is unjust: for there is no Covenant with God, but by mediation of some body that representeth Gods Person; which none doth but Gods Lieutenant, who hath the Soveraignty under God. But this pretence of Covenant with God, is so evident a lye, even in the pretenders own conscience, that it is not only an act of an unjust, but also of a vile and unmanly disposition. ${ }^{39}$

Immediately apparent from this dense passage is Hobbes's effort to deflate the divine covenant by transposing it from a material reality to the arena of the imagination: to claim a covenant immediately with God was to dishonestly conjure one in the mind. These pretenders were likely the Scottish Presbyterians, who agreed to the National Covenant of 1638 and entered into the Solemn League and Covenant with English Parliamentarians in $1643 .^{40}$ One such Scottish Presbyterian was the pastor Samuel Rutherford, whose Lex, Rex was the 'classic statement' of Covenanter political thought. ${ }^{41}$ This was a deeply scholastic text, arranged along the lines of affirmation and refutation of a series of questions. Although written by a Presbyterian, the influence of the Salamancan neoThomists bears this out. ${ }^{42}$ Therefore, while Rutherford has on occasion been grouped together with 
the English Parliamentarians, such as Henry Parker, ${ }^{43}$ the explicitly theological nature of the argument placed him within a distinct political genre that produced a series of debates in lengthy theologico-political treatises that ran parallel to the shorter pièces d'occasion typical of civil war pamphleteering. ${ }^{44}$

Lex, Rex was a reformed scholastic defence of the maxim 'nam constituens est major constituto', or 'the constituent is above that which is constituted'. ${ }^{45}$ This maxim was found in George Buchanan's De Jure Regni, published some 65 years earlier, but had gained fresh audience following the National Covenant. It was against the bishop John Maxwell that Rutherford positioned his argument, in which he combined contractualism drawn from the Politica genre of the Holy Roman Empire with scripture to aid an account of the people's power to constitute the monarch, and the corresponding power to depose at will. ${ }^{46}$ This cluster of concepts, which forms a contractualist variant of constituent power, had a far longer lineage in French and German Monarchomach thought, ${ }^{47}$ which Rutherford accessed through the jurist Johannes Althusius. ${ }^{48}$ Rutherford's adjustments formed the basis of a distinctive covenanter theology against which Hobbes positioned a line of argument in Leviathan. ${ }^{49}$

Rutherford's dispute with Maxwell had centred upon the role played by 'the people' in the constitution of the monarch. The maxim supposed that, in constituting the monarch, the people were superior to their creation. Daniel Lee has framed this as a debate over the Roman Law principle of 'divestiture': whether the people's original 'donation' of power was irreversibly given to the monarch. ${ }^{50}$ Though instructive, Lee's position erodes a second argument which supplemented the Roman Law case. This was an ontological argument that addressed the status ascribed to the mediation of God's acts in the establishment of monarchical office. Playing upon the Aristotelian schema of causes, John Maxwell had argued that an efficient cause-the entity which brings the effect into being - must contain the formal cause - the essence of the thing. If the monarch held power over life and death, this was not a power innately in the community, but one given by God. It followed, at least for Maxwell, that 'the people [were] not the efficient and constituent of a king', but only a tool of the efficient cause (i.e., God) to whom the power over life and death belonged. ${ }^{51}$ 
Rutherford's response was more sophisticated than a simple rejection of divestiture. Rutherford initially agreed that individuals did not 'have in themselves formally any ray of royalty or magistratical authority', though he distinguished two acts in the creation of a monarch: the 'institution' of the Office, and the 'constitution' of the person of that office. ${ }^{52}$ Whilst 'God hath immediately by law of nature appointed that there should be a Government', God 'mediately defined by the dictates of natural light in the community, that there shall be one, or many Rulers to govern the community..$^{53}$ God did not partake directly in the act of constitution; to constitute was to designate the authority of God, but that act was one held completely in the body of the people. ${ }^{54}$

For Rutherford, the power to constitute the person of the monarch was, in light of Maxwell's objection, a clarification of the form of constituent power found earlier in Buchanan and Althusius. This presupposed a vertical covenant with God, the sort made explicit in Monarchomach thought, and according to which the powers of institution and constitution could be appropriately designated. ${ }^{55}$ It was only through their prior covenant with God that a people capable of constituting the monarch came into being, and so their obligation to God superseded their obligation to the King. ${ }^{56}$ In practice, the corresponding power to depose that which was constituted was not arbitrary, but circumscribed within Rutherford's specifically Presbyterian considerations, and this meant that it was the duty of Charles I, as monarch of a Protestant nation, to act in accordance with the Protestant constitution. ${ }^{57}$

Rutherford's variety of constituent power narrated a joint enterprise entered into by king and people in order to defend the true religion. With it, the people's obedience to the monarch extended only so far as it coincided with their duty to God. Hobbes objected to this doubled-barrelled aspect of covenant. In placing religious law above secular law, Rutherford provided justification to disobey the monarch in the name of extra-political duties. These duties were, for Hobbes, an extension of a supposed covenant with God, which was nothing more than a fantastic construct of the imagination made possible by exploiting the debris thrown up by Scholastic sense perception. The historical God of Leviathan was representational. Because Hobbes was a materialist, who believed nothing existed 
beyond the motion and magnitude of bodies, he could have it no other way. God's presence in the temporal world was possible only through an activity of personation whereby they could be materially represented by a living individual. ${ }^{58}$ This proposition turned Rutherford's own language of 'mediation' on its head. Whereas, for Rutherford, God's power to constitute the person to fill the office of monarch was 'mediately' designated by the people, Hobbes, in the same passage that he refers to these 'pretenders', co-opted this language, pressing that the historical God was possible only 'by mediation of some body that representeth Gods Person'. Hobbes point was that the inflection of Scholastic philosophy in Rutherford's work had mistaken God's incorporeity for a real quality within the world. From this premise, it became possible for the Covenanters to suppose an immediate contract with God, which, for Hobbes, was nothing more than a fiction contrived from an ill-fitting combination of scripture, the 'vain and erroneous' philosophy of Aristotle, and 'fained, or uncertain history'. ${ }^{59}$

The immediate covenant with God was not the only fiction at work in Rutherford's argument, nor even the most important, but Hobbes was concerned that it laid the groundwork upon which a second fiction could be built that allowed Presbyterians to renege upon their duty of obedience to the monarch and justify their rebellion. This was the fiction of constituent power. Power, for Hobbes, was to be explained in accordance with his mechanistic physics. As he made clear in De Corpore, power was a present or future capacity to motion that would produce an effect. ${ }^{60}$ And so, when in Leviathan Hobbes apportioned to 'naturall power' the categories of 'prudence', 'eloquence', and 'liberality', he intended that these were labels that described manifestations of material power. ${ }^{61}$ In short, these were perceived effects brought about by immediate bodily motion. What Hobbes ruled out was the Aristotelian schema of causation that Rutherford had drawn upon to justify why the power to constitute ensured an ongoing superiority of constituent over constituted, and according to which the people retained the ability to dethrone the Monarch. This constituent power was not an effect of bodily motion, but what Hobbes called 'insignificant speech'. ${ }^{62}$ Hobbes agreed that material and efficient causes exist, insofar as they corresponded to bodies and motions of 
bodies, but he rejected formal and final causes, which were incompatible with the new mechanistic science. ${ }^{63}$ By rejecting essences and ends, Hobbes also revised the Scholastic worldview that made use of a perceived hierarchy intended to realise the immanent end of an object. Power was only the accident of a body, and could not be considered independent of that motion. Though one power may be lesser in skill or magnitude than another, it did not follow that there was an ongoing metaphysical priority of cause over effect or of one power over another without misconstruing the material way in which power was employed. ${ }^{64}$

On this point, Hobbes's target had been the Cardinal Bellarmine, who had defended the supremacy of the papacy over the temporal power of the monarch, but the argument cut through Rutherford's constituent power too. ${ }^{65}$ Rutherford made use of Aristotelian causation in order to supplement an act of power-i.e., the constitution of the person of the monarch-with further unjustified ornamentation-i.e., the contention that the constituents retain the right to depose the monarch if in conflict with Presbyterian teachings. Constituent power was not a material power but operated on the register of compound imagination. It was a set of strategic political arguments that combined a series of innocuous experiences into a viscerally charged fanciful image, which set the terms for how a group could act. This was the source of Hobbes's anger toward these 'vile and unmanly' pretenders. Rutherford did not formulate his argument as transparent, rational propositions over the rights and duties of citizens. Instead, he framed these rights in the naturalistic language of Aristotelian causation, presenting words as concrete things to shield them from dispute. For Hobbes, this was neither logical nor sincere, but a form of political subterfuge whose presentation played upon the passions of Presbyterians in order to excite them into sedition and convince them to betray civil authority in the name of a higher duty.

My proposition, however, is not that Hobbes intended to conceive of a covenant without constituent power. After all, Hobbes was similarly dissatisfied with absolutist theories that took the proper relation between ruler and the people to be one of passive obedience. ${ }^{66}$ For Hobbes, Rutherford's constituent power served as a metaphor through which the self-understanding of the 
imagined collective was organised according to particular rules that shaped the behaviour, expectations and understanding of individuals within their political community, whose creation they participated in. ${ }^{67}$ Accordingly, Hobbes foresaw that an adequate response did not only debunk the Presbyterian constituent power, but harnessed this same imagination toward a different end, namely one that took the Kingdom of God to be nothing else but the Commonwealth itself. ${ }^{68}$

With this in mind, an apparently unimportant choice of vocabulary in Leviathan has greater significance. Hobbes began chapter 18:

'A Common-wealth is said to be Instituted, when a Multitude of men do Agree, and Covenant, every one, with every one, that whatsoever Man, or Assembly of Men, shall be given by the major part, the Right to Present the Person of them all'. ${ }^{9}$

This passage occurs only a page before Hobbes's scornful attack on the Scottish Covenanters, and was the conceptual cornerstone upon which he built that critique. The term 'instituted' was a fresh addition to Leviathan. In the corresponding passage from chapter VI of De Cive, written prior to the publication of Lex, Rex, Hobbes did not use the term, but instead chose 'constitutionem' to describe the nature of the covenant, which was translated in Charles Cotton's 1651 English edition as 'constitute'. ${ }^{70}$ In the space of a page and a half, and without naming him, Hobbes had engaged three times with Rutherford's argument: he denounced the covenanters as 'pretenders' for the contract they claimed with God; he sardonically adopted Rutherford's own language of 'mediation' while turning that covenant on its head; and he revised the argument of De Cive, substituting 'constitution' for 'institution in light of Rutherford's distinction.

There was a superficial sleight-of-hand at play in this final move, as his decision to replace the term 'constitution' with 'institution' allowed Hobbes to circumvent some of the more obvious objections associated with the maxim, 'the constituent is greater than the constituted'. Nevertheless, there is more to the theoretical engagement than linguistic trickery. Though he wrote out the language of constituent power, the concept-at least as it appeared in Rutherford—was retained, though conjoined with the act of institution into a single covenant. ${ }^{71}$ Hobbes used representation to reframe 
constituent power as a normative justification for obedience, and not sedition. This involved a conceptualisation of constituent power through which the claim to the title 'constituent' was present, though unvoiced and intentionally equivocal. This was because, for Hobbes, there was no collective known as 'the people', only the person of the state. ${ }^{72}$ Pace Brito Vieira, however, this does not mean that constituent power was absent, because for Hobbes it was not a pre-commitment device of a unified constituent will, but a set of imaginative political claims about the foundation of the state and the collective identity related to it.

This entailed recasting the terms of Rutherford's covenant in order to demonstrate that the three moments of contracting - the vertical covenant that made the people one before God; the institution of the office of the monarch by God; and the constitution of the person of the office by the people—were a single covenant of institution. Hobbes's famous passage from chapter 17 reads:

A Multitude of men are made One Person, when they are by one man, or one Person, Represented...for it is the Unity of the Representer, not the unity of the Represented, that maketh the Person One. And it is the Representer that beareth the Person, and but one Person: And Unity, cannot otherwise be understood in Multitude ${ }^{73}$

The unity of a group depended upon a representative who could 'bear the person' of that group, and this meant that only the act of institution between natural persons produced a collective identity. This was rooted in a provocative account of personhood that Hobbes thought necessary to serve his general purpose, namely, to ensure there was no collective identity separable from the sovereign and the state. Personhood was a juristic device through which Hobbes sought to make sense of how actions performed by a representative were to be attributed to the thing being represented. ${ }^{74}$ The act of personation involved the theatrical representation of a persona, and so to 'bear one's person' was to represent the character of another. ${ }^{75}$ Because groups are composed of numerous individuals, Hobbes saw it necessary to introduce an intermediary 'person': the state, a character capable of representing the covenanting individuals as a single group. Therefore, through the act of institution, two persons were created: the state and the sovereign. In covenanting, the multitude were made a 
unity when represented by the person of the state, which stood in place of the nominal label, 'the people'. ${ }^{76}$ The state was a person 'by fiction'; it was a construct and so lacked the rational capacity to take responsibility for actions attributed to it. As a construct, it could not speak or act. It therefore required another artificial person, the sovereign, to bear its person, and act on its behalf. Hobbes theory of representation was the tool through which the state exhaustively served as the vessel of collective identity, and that its actions were performed only by the sovereign. This was because he believed that a group could act only through an individual representative, without which there was no way of allocating collective responsibilities to actions. ${ }^{77}$

Forsyth has suggested the covenant gave 'the unity latent in its multiplicity a distinct, appropriate, instituted shape and form'. ${ }^{78}$ This mistakes the direction in which Hobbes's argument ran. It was not that the identity was latent, but that there was no collective identity prior to the covenant. The conceptual disconnection between the two was vital if Hobbes was to adequately diffuse the position of Rutherford, who assumed there was a body of the people. 'The people' of Lex, Rex breached the Hobbesian account of personhood because without a representative they formed an inchoate mass without a means of identifying a single will. By naming that collective 'the people', Rutherford was one of many writers who conflated the multitude of individuals with the description of a unified subject, an elision that made it impossible to adequately attribute actions to the collective. ${ }^{79}$ The key, for Hobbes, was the discontinuity between multitude and the state. There was no trace of a collective constituent subject prior to the covenant. ${ }^{80}$ The upshot was that the prepolitical entity that may have laid claim to acting as constituent power-that is, the multitude mistaken for a collective agent—ceased to exist following the creation of the state.

In excluding the people as a unified collective within the state of nature, Hobbes presented an objection to Rutherford that held even in the terms of Rutherford's own account of Aristotelian causation. The individuals who comprised the state held no authority over the person that was authored—namely the sovereign—because their collective identity did not temporally precede the creation of the commonwealth. In short, Hobbes account of representation fundamentally 
reconfigured the image to which the label of constituent power could be attributed in two ways: first, the seat of collective identity was co-original with the person of the sovereign; second, the collective identity was capable of acting only through the person of the sovereign. The first point ensured the collective were not the constituents of the sovereign; the second ensured the act of institution invested them into an ongoing and active 'authorisation' (i.e. responsibility for the sovereign's actions) through the person of the state. ${ }^{81}$

This is a qualification upon Forsyth's argument that Hobbes's constituent power 'acted once and only once', having no life beyond the founding. ${ }^{82}$ The metaphor of constituent power, though intentionally difficult to pin down, served as the basis of a political imaginary by impressing upon the mind of the reader of Leviathan that, as authors of the state, they were not endowed with a capacity to dissolve it, but engaged in a continual joint-enterprise of authorisation. Through the person of the state, the individuals identified themselves as co-authors of the sovereign's words and actions. Hobbes was vitally aware of the significance of this sort of symbolic attribution, for, as he wrote in Behemoth, 'the power of the mighty hath no foundation except in the opinion and belief of the people. ${ }^{83}$ The state itself existed only in the imagination of citizens whose individual practices allowed responsibility to be attributed from the sovereign to the state, and continued to exist only so long as they continued to buy into that fiction. ${ }^{84}$ Even when understood as a claim that pressed on the imagination, constituent power was world-making. This was not because the constituent's fountain power was a substantive capacity of a group who bore it and were therefore capable of creating new constitutions, but because, for Hobbes, it was another of those conjured phantasms that assisted in forging the imagery of the political world towards which it was directed. In doing so, it forged the image of the Leviathan and the political obligations that followed from it.

\section{CONSTITUENT POWER AND THE IMAGINATION}


Contemporary democratic theorists reproduce assumptions about constituent power that Hobbes had sought to debunk. Although there are important differences in the morphologies of contemporary arguments about constituent power when compared to Rutherford, each assumes it to be a privileged mode of collective action fundamentally separate from, and superior to, the institutional structure of the state. The excursion into Leviathan has sought to provide a different conclusion, namely that Thomas Hobbes argued that constituent power should not be understood as a capacity or physical power, nor a property of any sort, but as a nominal label that is mobilised as part of a partisan claim to forge a new common inferential framework from which citizens can draw. ${ }^{85}$ By using Hobbes's challenge to Rutherford, my intention has been to throw into sharper relief the variety of ways in which constituent power can be employed in the process of political argument, and the variety of ends to which it can be directed. In challenging the orthodoxy around constituent power, I have disputed the assumption that it is the uncontested property of a democratic collective. Instead I have provided a wider analytical lens that sheds light on how constituent power is used as a genre of claim-making within political discourse.

When understood, as it was for Hobbes, as a partisan claim that leans on the imagination, constituent power should be seen as a component of political arguments through which the individual intends to secure a form of political authority for themselves or the group on behalf of whom they speak; its meaning is made more malleable, and it is opened to political contestation with a range of effects. For instance, a claim about the meaning and content of constituent power might determine a status (one $i s$ the constituent power), or it might identify a property, a capacity or a right (one has constituent power). It is able to draw and redraw the boundary that demarcates the people. It is also able to attach privilege to other forms of collective agents of varying scales and composition (such as the state, the nation, the party, or the multitude) or individuals who may act on their behalf (for instance, the sovereign, the dictator, or the Reichspräsident). These claims, as Hobbes showed, also substantiate further criteria, namely, how, when, where and to what end it is appropriate for these groups to engage in political action: they might lay the justificatory groundwork for rebellion 
or ensure obedience; these arguments might demarcate the appropriate subject of constitutionwriting, ${ }^{86}$ or channel collective action toward the symbolic acclamation of a strong leader; ${ }^{87}$ they may even be distanced from collective acts, and associated with the capacity of the sovereign to select ministers to govern. ${ }^{88}$ How collective agency is shaped and where it is channelled depends upon the constructed morphology of constituent power, as well as how that morphology is advanced in argument. ${ }^{89}$ The prevailing interpretation that defines constituent power as a capacity is only one among many variations. To interpret it as an imaginative fiction is to observe with a wider-angle analytic lens capable of grappling more effectively with the differences between the diverse formulations of collective agency available to those who make use of constituent power.

Constituent power is capable of being used in this way because it is a particularly important type of claim. This is not because constituent power designates an exceptional or extraordinary activity but because it is a significant nodal point within the constellation of concepts that inform the construction of a collective identity, insofar as constituent power is itself often connected to the origin of something pertinent to that identity (such as the legal system that institutionally constrains it). Convincing others about the ownership of that origin, however elusive or insecure, assists in the distribution of political capital. In short, a partisan depiction of constituent power serves as a fulcrum within a political imaginary around which political space is organised, substantiating, among other things, who possesses authority (insofar as collective agents can be composed in various ways), the sorts of political action that authority can legitimise and the end to which those actions are to be directed.

This is to revise the relationship between constituent power and the imagination. It is not to present the imagination as a constituent power-as an infinitely creative political impulse ${ }^{90}$ - but to present constituent power as a fiction of the imagination — as a fiction aspect of the shared symbolic world in which we live. Accordingly, although the imagination provides manifold ways of instituting a symbolic world, for a claim over the meaning and content of constituent power to be successful, it must be accepted by an audience. This exposes both the strength and the vulnerability of Hobbes's 
presentation of constituent power as a fiction. The danger was that by exposing the inner workings of the imagination, Hobbes risked weakening the persuasive force behind his own efforts to press the same passionate triggers in his audience. Hobbes was attuned to this danger. He was, after all, well-versed in the art of rhetoric and sensitive to how arguments were to be presented in such a way that they would be received with acceptance. Hobbes shored up his own position by ensuring his account of personation was consonant with his materialist teardown of the imagination. Under the principles of his mechanistic physics, fictional persons, such as the state, were possible only when represented by a human capable of rational action. Hobbes openly avowed the artificiality of this representation, ${ }^{91}$ and wilfully embraced that he was fighting one fiction with another. His wager was that if one were to accept his critique of the imagination, his account of personation was the only adequate alternative for collective representation.

It is on this point that modern scholarship is less attentive. When constituent power is closely associated with a capacity belonging to the people, the broader phenomenon of how these claims are constructed, advanced and legitimated is occluded. This is detrimental, because it masks those instances where claims over constituent power are hijacked (as Hobbes's own argument does), or simply misfire. Among contemporary theorists, one tendency is to argue that when hijacked, one is no longer dealing with constituent power. ${ }^{92}$ This is evident even in Jason Frank's excellent assessment of the use of imagination in the Federalist Papers. Frank sees constituent power lacking in the writings of the Anti-Federalists due to their demand that the constitution was authorised by the signature 'We, the States' rather than 'We, the People'. ${ }^{93}$ Although Frank is very much aware of how the imagination produces the requisite symbolism through which a crowd understand understands itself as one, he combines this with a foundational assumption that pins constituent power to a particular collective agent. When circumscribed in this way, scholarship is less attentive to the way constituent power is constructed in confrontation between partisans, and it is less responsive to hijackings and misfirings. Hobbes aids us with this problem, because he recognised the surprising flexibility of constituent power, and this rendered it a battle over words. He was 
cognisant that he was a partisan in that battle, and this required both the tactical awareness and the ability to respond to how one's opponents had tapped into the imagination of their audience.

\section{CONCLUSION}

The intention of this article has been to shed some light on the conceptual history of constituent power with an eye toward how this conceptual history can unsettle the received view of constituent power in contemporary democratic theory. Against the prevailing view that constituent power is the extraordinary concrete capacity of a collective to found a constitution, I have sought to show that it is a genre of political claim-making. My excavation of Hobbes's sometimes opaque challenge to the Presbyterians has aided this argument.

Hobbes appreciated that one prominent aspect of political power entailed convincing one's audience of ownership of that power, and this involved myth-making and fiction-writing. ${ }^{94}$ Constituent power was one such device through which this could be achieved. For Hobbes, the Presbyterians who made use of arguments about constituent power were engaged in an exploitative enterprise that placed in the minds of believers an understanding that they possessed a right to challenge or disobey sovereign command that followed from their power to constitute him. This, for Hobbes, was derived from a flawed interpretation of sense perception that ascribed a reality to immaterial things. The arguments that individuals could be united as a people through an immediate contract with God, that their collective action could constitute a monarch, and that in being the cause of that monarch, they held authorial power over their creation, were, for Hobbes, constructs of the imagination that ornamented physical actions of individuals with supplementary normative imagery that excited citizens into sedition. This was because constituent power was a metaphor through which groups understood the range of possible actions available to them. Though he intended to reveal the 'fancy' of the Presbyterian constituent power, he also harnessed it for his own political project because he recognised that imagination was central in maintaining the fictional attribution of political responsibility that allowed the state to exist. 
Accordingly, I have argued that constituent power should not be understood as the collective capacity for innovation, but as a 'fiction' that accords us the means to imagine ourselves within political communities. One may reply that it is patently fictive insofar as it is an element of language, and the same could be said of all language. My proposition is finer than this. The content of that fiction is important, as is the practice of its construction. The label 'constituent power' is not only a scholarly 'placeholder for worthy practices' of extra-institutional participation. ${ }^{95}$ As Hobbes demonstrated, it is also a partisan construction. Political theorists must be more attentive to how the meaning of 'constituent power' — and not only peoplehood—is formed at the vernacular level in aid of particular political causes. This point is left under-theorised when constituent power is associated with a relatively unchanging form of political agency that varies only according to the political actor to which it is ascribed. In constructing to these images, and those images being accepted, one creates a social world complete with constitutive rules, a location of authority, and a place for living. This is a world-constituting act even if this is orthogonal to how constituent power is commonly understood to create social identities. The meaning of constituent power supplements the names of political collectives with the normative ornamentation, establishing why 'the people' or 'the nation' bears weight. The normative significance ascribed to 'the people' is not self-evident; it is formed through laying claim to constituent power. 


\section{REFERENCES}

${ }^{1}$ Thomas Hobbes, Leviathan: The English and Latin Texts, ed. Noel Malcolm (Oxford: Oxford University Press, 2012), 266.

${ }^{2}$ Andreas Kalyvas, “Constituent Power,” Political Concepts 3, no.1 (2013):4-5.

${ }^{3}$ Mark Wenman, Agonistic Democracy: Constituent Power in the Era of Globalisation (Cambridge: Cambridge University Press, 2013), 5, 64.

${ }^{4}$ As the potentiality of a multitude, see Antonio Negri, Insurgencies: Constituent Power and the Modern State, ed. Maurizia Boscaglia (Minneapolis: University of Minnesota Press, 1999), 303-36. As insurgent citizenship, see Jason Frank, Constituent Moments: Enacting the People in Post-Revolutionary America (Durham: Duke University Press, 2010); Martin Loughlin, “The Concept of Constituent Power," European Journal of Political Theory 13, no.1 (2014):227-31.

${ }^{5}$ Especially Cees Leijenhorst, The Mechanisation of Aristotelianism: The Late Aristotelian Setting of Thomas Hobbes' Natural Philosophy (Leiden: Brill, 2002).

${ }^{6}$ Andrew Arato, The Adventures of the Constituent Power (Cambridge: Cambridge University Press, 2017), 56; Mónica Brito Vieira, Elements of Representation in Hobbes (Leiden: Brill, 2009), 164.

7 Andreas Kalyvas, "Popular Sovereignty, Democracy and the Constituent Power," Constellations 12, no.2 (2005); Martin Loughlin, "Constituent Power Subverted: From English Constitutional Argument to British Constitutional Practice," in The Paradox of Constitutionalism, ed. Martin Loughlin and Neil Walker (Oxford: Oxford University Press, 2007).

${ }^{8}$ For an overview, see Martin Loughlin and Neil Walker, The Paradox of Constitutionalism (Oxford: Oxford University Press, 2007). Loughlin and Walker neglect those who argue that constituent power serves as a regulative principle to assess the internal function of constitutional decision-making. See Philip Pettit, On The People's Terms (Cambridge: Cambridge University Press, 2013), 285-92. Pettit's position is beyond the scope of this argument.

${ }^{9}$ Kalyvas, "Constituent Power," 1.

${ }^{10}$ Similar sentiments are expressed in Ernst-Wolfgang Böckenförde, “The Constituent Power of the People: A Liminal Concept of Constitutional Law," in Constitutional and Political Theory, ed. Mirjam Künkler and Tine Stein (Oxford: Oxford University Press, 2017), 171.

${ }_{11}$ Aristotle, The Politics, trans. C.D.C Reeves (Indianapolis: Hackett, 1998), 1252a.24-25. Kalyvas cites this line as the epigraph to his argument.

${ }^{12}$ On decontestation, see Michael Freeden, Ideologies and Political Theory (Oxford: Clarendon, 1996), 75-77. On temporal arrogation as a technique of decontestation, see Michael Freeden, The Political Theory of Political Thinking (Oxford: Oxford University Press, 2013), 92-131.

${ }^{13}$ Kalyvas, "Popular Sovereignty," 226. 
${ }^{14}$ George Lawson, Politica Sacra et Civilis, ed. Conal Condren (Cambridge: Cambridge University Press, 1992), 57-76. Kalyvas's source for this appears to be Julian Franklin, who argued that Lawson's distinction between majestas realis and majestas personalis, analogous to that of 'constituent' and 'ordinary' power, was introduced as a general challenge to royalist opposition during the interregnum. Franklin, unlike Kalyvas, stressed that the distinction was by no means original to Lawson, but was taken from continental jurisprudence, particularly work of Christoph Besold. Julian Franklin, John Locke and the Theory of Sovereignty (Cambridge: Cambridge University Press, 1978), 64-69.

${ }^{15}$ Kalyvas, "Popular Sovereignty," 225. Kalyvas's dichotomy is problematic. Among the canonical theorists of sovereignty, creative powers were essential to sovereignty; command was the means through which that creation was express, particularly in the constitution of a magistrate [magistratum constituere]. Daniel Lee, Popular Sovereignty in Early Modern Constitutional Thought (Oxford: Oxford University Press, 2016), 146. Hobbes was familiar with this tradition, and he recognised the sovereign power to appoint [constituere]. Thomas Hobbes, De Cive: The Latin Version, ed. Howard Warrender (Oxford: Oxford University Press, 1983), 147.

${ }^{16}$ Ibid.

${ }^{17}$ Ibid., 226.

${ }^{18}$ See especially the work on the distinction between sovereignty and government in Daniel Lee, “'Office is a Thing Borrowed': Jean Bodin on Offices and Seigneurial Government," Political Theory 41, no.3 (2013); Richard Tuck, The Sleeping Sovereign: The Invention of Modern Democracy (Cambridge: Cambridge University Press, 2016).

${ }^{19}$ Murray Forsyth, “Thomas Hobbes and the Constituent Power of the People," Political Studies 29, no.2 (1981). Others argue that Hobbes influenced Sieyèsian and Schmittian variants of constituent power, but do not claim Hobbes held an independent conception of constituent power. István Hont, “The Permanent Crisis of a Divided Mankind: 'Contemporary Crisis of the Nation State' in Historical Perspective," Political Studies 42, no.s1 (1994); Duncan Kelly, "Carl Schmitt's Political Theory of Representation," Journal of the History of Ideas 64, no.1 (2004).

${ }^{20}$ Brito Vieira, Elements, 164.

${ }^{21}$ For example, Thomas Hobbes, "De Corpore," in The English Works of Thomas Hobbes, Vol.I, ed. William Molesworth (London: John Bohn, 1839), 387-410; Thomas Hobbes, Thomas White's De Mundo Examined, trans. Harold Whitmore Jones (London: Bradford University Press, 1976), fols.331-57v; Thomas Hobbes, Elements of Law Natural and Political, trans. J.G.A. Gaskin (Oxford: Oxford University Press, 1994), 22-34; Hobbes, Leviathan, 22-46. The role of imagination in Leviathan is often understated. Exceptions include Robin Douglass, "The Body Politic "is a Fictitious Body": 
Hobbes on Imagination and Fiction," Hobbes Studies 27, no.2 (2014); Juhana Lemetti, Imagination and Diversity in the Philosophy of Hobbes (Helsinki: Helsinki University Press, 2006).

${ }^{22}$ Hobbes, "De Corpore," 91-92.

${ }^{23}$ Hobbes, Leviathan, 1122.

${ }^{24}$ Ibid., 24. Hobbes wrote only generally of the Aristolelian Scholasticism with which he would have been familiar. Important contributions to the genre included Gregor Reisch, Margarita Philosophica Nova, ed. Lucia Andreini (Salzburg: Institut für Anglistik und Amerikanistik 2002); Jacopo Zabarella, De Rebus Naturalibus (Leiden: Brill, 2016).

${ }^{25}$ Aristotle, De Anima, trans. Christopher Shields (Oxford: Clarendon, 2016), 418a3-6.

${ }^{26}$ Ibid., 242a17-24.

${ }^{27}$ Leijenhorst, Mechanisation of Aristotelianism, 59; Katherine Park, "The Organic Soul," in The Cambridge History of Renaissance Philosophy, ed. Charles B. Schmitt and Quentin Skinner (Cambridge: Cambridge University Press, 1992), 471. See especially Paul of Venice, Summa Philosophiae Naturalis (Venice, 1504).

${ }^{28}$ Hobbes, “De Corpore," 102. Hobbes, Leviathan, 1076.

${ }^{29}$ Hobbes, "De Corpore," 389.

${ }^{30}$ Hobbes, De Mundo Examined, fol.338.

${ }^{31}$ Hobbes, Leviathan, 26.

${ }^{32}$ Ibid., 29-30.

${ }^{33}$ Hobbes, Leviathan, 1076-84. On Hobbes's nominalist response to the Scholastics, see Ben Holland, "Sovereignty as Dominium?: Reconstructing the Constructivist Roman Law Thesis," International Studies Quarterly 54, no. 2 (2010): 460-65.

${ }^{34}$ Hobbes, Leviathan, 958.

${ }^{35}$ Hobbes, De Mundo Examined, fol.339.

${ }^{36}$ Ibid., 1082; Thomas Hobbes, Behemoth; or, The Long Parliament, ed. Ferdinand Tönnies (Chicago: University of Chicago Press, 1990), 41-43.

${ }^{37}$ Hobbes, Leviathan, 1106; "Six Lessons to the Savillian Professor of the Mathematics," in The English Works of Thomas Hobbes, Vol.VII, ed. William Molesworth (London: Routledge, 1992), 335.

${ }^{38}$ Arash Abizadeh, "The Representation of Hobbesian Sovereignty: Leviathan as Mythology," in Hobbes Today: Insights of the 21st Century, ed. S.A. Lloyd (Cambridge: Cambridge University Press, 2014), 116-24; James Martel, Subverting the Leviathan: Reading Hobbes as a Radical Democrat (New York: Columbia University Press, 2007), 120-22; Patricia Springborg, "Thomas Hobbes and Cardinal Bellarmine: Leviathan and 'The Ghost of the Roman Empire'," History of Political Thought 16, no.4 (1995).

${ }^{39}$ Hobbes, Leviathan, 266. 
${ }^{40}$ See Behemoth, where Hobbes denounced the signing of the Scottish National Covenant of 1638, which he understood as 'a Covenant among themselves, which impudently they called a Covenant with God'. Hobbes, Behemoth, 28. Noel Malcolm, editor of the Clarendon edition of Leviathan, also submits that this passage refers to the Scottish Covenanters. See Hobbes, Leviathan, 267, editorial fn.b.

${ }^{41}$ John Robertson, The Scottish Enlightenment and the Militia Issue (Edinburgh: John Donald, 1985), 57.

${ }^{42}$ John Coffey, Politics, Religion and the British Revolutions: The Mind of Samuel Rutherford (Cambridge: Cambridge University Press, 1997), 152.

${ }^{43}$ For example, John Sanderson, “Conrad Russell's Ideas,” History of Political Thought 14, no.1 (1993).

${ }^{44}$ Richard Tuck, Natural Rights Theories: Their Origin and Development (Cambridge: Cambridge University Press, 1979), 144.

${ }^{45}$ Samuel Rutherford, Lex, Rex (London: John Field, 1644), 377.

${ }^{46}$ Ibid., 377. Though Rutherford does not employ the precise phrase 'constituent power', which, to my knowledge, does not appear in English until debates around the 1707 Act of the Union, he does employ various cognates, such as 'the power to constitute', or 'the constituent cause', which I take to be equivalent.

${ }^{47}$ Especially Lee, Popular Sovereignty, 142-49, 230-253.

${ }^{48}$ Rutherford, Lex Rex, 129-130, 141-142, 417-418; Johannes Althusius, Politica, ed. Frederick S. Carney (Indianapolis: Liberty Fund), 63. On the influence of Althusius on Rutherford and other Covenanters, see Robert von Friedeburg, "From Collective Representation to the Right to Individual Defence: James Steuart's Ius Populi V indicatum and the Use of Johannes Althusius' Politica in Restoration Scotland," History of European Ideas 24, no. 1 (1998). Althusius was a common touchstone for early $20^{\text {th }}$ century theorists of constituent power. See Carl Schmitt, Constitutional Theory, ed. Jeffrey Seitzer (Durham: Duke University Press), 126; Egon Zweig, Die Lehre vom Pouvoir Constituant (Tübingen: J.C.B. Mohr, 1909).

${ }^{49}$ Among recent scholarship, only Colón-Ríos has recognised the vocabulary of constituent power in the work of Rutherford, although his references are short on analytical implications. Joel Colón-Ríos, “Five Conceptions of Constituent Power," Law Quarterly Review 130, no.2 (2014):32325.

${ }^{50}$ Lee, Popular Sovereignty, 295-99.

${ }^{51}$ John Maxwell, Sacro-Sancta Regum Majestas (Oxford, 1644), 131-32. 
${ }^{52}$ Rutherford, Lex, Rex, 6, 147. Rutherford, however, did not believe, as Maxwell did, that God imparted a monarchical essence in the king, rejecting the Scotian doctrine of univocity upon which Royalists constructed their arguments. Ibid., 111-15.

${ }^{53}$ Ibid., 5. Emphasis in original.

${ }^{54}$ For Rutherford on constitution and institution, see John D. Ford, "Lex, rex iusto posita: Samuel Rutherford on the Origins of Government," in Scots and Britons: Scottish Political Thought and the Union of 1603, ed. Roger A. Mason (Cambridge: Cambridge University Press, 1993), 267-72.

${ }^{55}$ Rutherford, Lex, Rex, 99. Cf. Stephanus Junius Brutus, Vindiciae, contra Tyrannos, ed. George Garnett (Cambridge: Cambridge University Press, 1994), 21-35.

${ }^{56}$ Rutherford, Lex, Rex, 97.

${ }^{57}$ Ibid., 103.

${ }^{58}$ Hobbes, Leviathan, 776. Abizadeh notes that Hobbes's representational God was made possible only through the account of personation in Leviathan. Arash Abizadeh, "Hobbes's Conventionalist Theology, the Trinity, and God as an Artificial Person by Fiction," The History Journal 60, no.4 (2017). It would be a mistake, however, to assume his representative politics was a product of his representational theology. Brito Vieira, Elements of Representation, 209.

${ }^{59}$ Hobbes, Leviathan, 958.

${ }^{60}$ Hobbes, "De Corpore," 127.

${ }^{61}$ Hobbes, Leviathan, 132.

${ }^{62}$ Ibid., 24.

${ }^{63}$ Hobbes, "De Corpore," 131-32. Noel Malcolm argues for the intrusion of Aristotelian hylomorphism into Hobbes civil (but not natural) science insofar as a formal cause can be interpreted as a category of intentionality. Noel Malcolm, Aspects of Hobbes (Oxford: Oxford University Press, 2002), 151-52. If Hobbes made use of the Aristotelian form/matter distinction to resolve a difficulty over intentionality, he did so within a circumscribed remit, and this did not allow Aristotelian physics to become an explanatory basis for civil science.

${ }^{64}$ Hobbes, Leviathan, 914.

${ }^{65}$ Although a critic of Bellarmine, Rutherford was not a critic as Hobbes was. Constituent power, for Rutherford, was the reformed scholastic alternative to the supremacy of the papacy. Rutherford, Lex, Rex, 17.

${ }^{66}$ Quentin Skinner, "A Genealogy of the Modern State," Proceedings of the British Academy 162 (2009): 342.

${ }^{67}$ Although she excludes constituent power, Brito Vieira appreciates this aspect of Hobbes's covenant. Brito Vieira, Elements, 177.

${ }^{68}$ Hobbes, Leviathan, 978. 
${ }^{69}$ Ibid., 264.

${ }^{70}$ See Hobbes, De Cive: Latin Version, 144; Thomas Hobbes, De Cive: The English Version, ed. Howard Warrender (Oxford: Oxford University Press, 1983), 100. Hobbes's Latin translation of Leviathan, published in 1668, employed the term 'institutionem'. Hobbes, Leviathan, 265. I therefore take it as an understandable mistranslation of the Latin that renders the term 'instituted' in the Cambridge edition of De Cive. See Thomas Hobbes, On The Citizen, trans. Richard Tuck (Cambridge: Cambridge University Press, 1998), 85. The two terms are employed interchangeably within Elements of Law, suggesting that he possibly saw no important distinction at that time. Hobbes, Elements, 109.

${ }^{71}$ When in Leviathan Hobbes did use the term 'constitute', he de-dramatized it by associating it with the activity of cheirotonia - the election of a pastor-or with the sovereign's power to select judges. He explicitly distanced this from commonwealth foundation. Hobbes, Leviathan, 273, 838. The latter was in keeping with the early modern understanding of sovereignty.

${ }^{72}$ See especially Skinner, “A Genealogy of the Modern State," 344.

${ }^{73}$ Hobbes, Leviathan, 248.

74 Ibid., 244-45.

${ }^{75}$ Hobbes used 'person' ambiguously, referring to both actors and characters. Fleming advances a convincing case to associate 'person' with 'character'. Sean Fleming, "The Two Faces of Personhood: Hobbes, Corporate Agency and the Personality of the State," European Journal of Political Theory (2017, Forthcoming).

${ }^{76}$ Hobbes, Leviathan, 260.

77 In accordance with Hobbes's commitment to the new science, this was a flattened representation that saw words as signs of thought without residuum, and not the older symbolic signification of resemblance and analogy. On Hobbes's epistemology of representation, see Ben Holland, The Moral Person of the State: Pufendorf, Sovereignty and Composite Polities (Cambridge: Cambridge University Press, 2017), 208-21.

${ }^{78}$ Forsyth, "Hobbes and Constituent Power," 199.

${ }^{79}$ Hobbes, Leviathan, 280.

${ }^{80}$ Ibid., 248. Also, Quentin Skinner, “Hobbes on Representation,” European Journal of Philosophy 13, no.2 (2005):170.

${ }^{81}$ Brito Vieira, Elements, 235-53.

${ }^{82}$ Forsyth, "Hobbes and Constituent Power," 201.

${ }^{83}$ Hobbes, Behemoth, 16.

${ }^{84}$ Douglass, "The Body Politic 'is a Fictitious Body"; David Runciman "What Kind of Person is Hobbes's State? A Reply to Skinner," Journal of Political Philosophy 8, no.2 (2000):273. 
${ }^{85}$ This understanding of constituent power has much in common with Jonathan White and Lea Ypi's assessment of the partisan construction of peoplehood. They contrast this with the 'contestation-based' alternative, which 'over-politicises' the question of peoplehood and becomes 'insensitive to the different ways claims are advanced in the public sphere'. Voluntarist interpretations of constituent power are indicative of the contestation-based approach. Jonathan White and Lea Ypi, "The Politics of Peoplehood," Political Theory 45, no.4 (2017):454; The Meaning of Partisanship (Oxford: Oxford University Press, 2016), 164-184.

${ }^{86}$ Emmanuel J. Sieyès, "What is the Third Estate?," in Political Writings, ed. Michael Sonenscher (Indianapolis: Hackett, 2003).

${ }^{87}$ Carl Schmitt, Constitutional Theory, 271-79.

${ }^{88}$ See fn.15, fn.71 above.

${ }^{89}$ There are limits to the plasticity of constituent power's morphology, and this may mean it is more amenable to sovereign politics. See Adam Lindsay, "Hannah Arendt, the Problem of the Absolute and the Paradox of Constitutionalism, or: 'How to Restart Time within an Inexorable Time Continuum'," Philosophy and Social Criticism 43, no.10 (2017).

${ }^{90}$ E.g., Jason Frank, Publius and Political Imagination (Lanham: Rowman \& Littlefield, 2012); Zoran Oklopcic, Beyond the People: Social Imaginary and Constituent Imagination (Oxford: Oxford University Press, 2018).

${ }^{91}$ See Brito Viera, Elements, 239-241

${ }^{92}$ Kalyvas, Constituent Power, 10; Negri, Insurgencies, 22.

${ }^{93}$ Frank, Publius and Political Imagination, 27.

${ }^{94}$ Abizadeh, "Leviathan as Mythology," 133.

${ }^{95}$ Zoran Oklopcic, "Three Arenas of Struggle: A Contextual Approach to the Constituent Power of "The People'," Global Constitutionalism 3, no.2 (2014):227. 